\title{
TTR
}

Traduction, terminologie, re?daction

\section{Translating (With) the Speculum}

\section{Barbara Godard}

Volume 4, numéro 2, 2e semestre 1991

Traduire la théorie

URI : https://id.erudit.org/iderudit/037095ar

DOI : https://doi.org/10.7202/037095ar

Aller au sommaire du numéro

Éditeur(s)

Association canadienne de traductologie

ISSN

0835-8443 (imprimé)

1708-2188 (numérique)

Découvrir la revue

Citer cet article

Godard, B. (1991). Translating (With) the Speculum. TTR, 4(2), 85-121.

https://doi.org/10.7202/037095ar d'utilisation que vous pouvez consulter en ligne.

https://apropos.erudit.org/fr/usagers/politique-dutilisation/ 


\section{Translating (With) the Speculum}

\section{Barbara Godard}

\section{Reading "with"}

"With" is the operative term. In this essay, I am concerned with a theory of translation as combinatory rather than substitution as I read with Luce Irigaray and Hélène Cixous who analyze and set in play theories of exchange of signs, of languages and bodies.

\section{Gender as the (im)possibility of translation}

Gender I understand to designate the apparatus of production of sexual difference as binary (asymmetric) relations. A system regulating differences, gender inflects regimes of sign relations including those of exchange. This might be rewritten as "including those of translation (transcoding)." The movement from "exchange" to "translation" takes place within semiotics when Saussure's concern with relations and his description of signification as the exchange of values within a system (Saussure, p. 115) is reworked by Hjelmslev into a "general calculus" of dependences in sign systems understood as "abstract transformation systems" characterized by "translatability" (Hjelmslev, p. 23, pp. 108-109). Society is conceptualized in terms of a theory of communication where rules of kinship and linguistic rules, along with economic rules, set in place systems of circulation of symbolic value (LéviStrauss, 1967, p. 82). Through the consolidation of inner bonds, a collective identity is produced for each group differentiated through an exchange, for each clan, for each language. In an exchange under the rule of reciprocity, groups fix their interrelation as one of difference with respect to an inside and an outside. In this way, are produced 
woman as a category within a kinship system of sexual difference and translation within a signifying system of linguistic difference. Relational terms, both distinguish and bind to a common internally differentiated identity, but are not identities. Performances, rather, in that like metaphor they deploy performatives, promising rather than giving (Derrida, 1982, p. 209).

I shall attempt to explore the overlapping relational systems of gender and translation through the triad law, desire, language in various formulations - and critiques - of the rule of exogamy. For anthropologists such as Claude Lévi-Strauss, (and before him a large group that includes Émile Durkheim and Marcel Mauss working on the economy of the gift or potlatch) exogamy or a generalized economy of exchange (Lévi-Strauss, 1967, p. 63) is crucial in the reproduction of culture, where culture is understood primarily as a set of signifying practices. Feminists, especially Luce Irigaray, have offered a critical exegesis of the operations of this construction of exchange and elaborated an alternative economy of relations. From the "Traffic in Women" (Goldman) there is a move to "reading with" women (Cixous, 1990). From substitution to interconnection. I shall first read Luce Irigaray's work as a theory of sign manipulation, that is, as a general theory of translation or semiotic transcoding (Jakobson, 1963, p. 79) with which, in a second phase, to examine the operations of a restricted theory of translation or translation proper (Jakobson, 1963, p. 79) as manifest in the practice of translating French feminist theory. Translating by "lapse and bounds" (Cixous, 1986, p. 96). My discussion will centre on the exegesis of metaphor and metonymy, that is on the relations of what Irigaray terms "the mechanics of solids" and "the mechanics of fluids" to economies of signification (Irigaray, 1985b).

\section{Translation, living on...}

Andrew Benjamin has argued that "the possibility of translation is the possibility of philosophy" (Benjamin, p. 4) which relation I shall rewrite as "the possibility of translation is the possibility of theory." Translation is linked to the "possibility of reinscription" so that translation becomes "the question of what allows texts/language to live on"... "[Theory] lives on in translation and [...] translation survives even philosophy [theory]" (Benjamin, p. 85). Translation confronts the text 
as other, "as the site of differential plurality" (Benjamin, p. 84) and allows for the interpretation of the word as a site of conflict, as the "recognition of non-correspondence as non-correspondence" (Benjamin, p. 176). Interpretation is a process in which what is presented is not the object of interpretation, rather as it proceeds, an initial presentation points to something further that was not, at first, presented. What seemed to be original is not independent of the interpretive chain, but "always already a translation" (Benjamin, p. 147). In Benjamin's view, there is no inside/outside of translation.

This (im)possibility of translation is the condition of interpretation, of theory. Concern is shifted from the "relationship between the interpretation and object of interpretation" to "the implications and presuppositions of that particular interpretation or translation" (Benjamin, p. 179), from axiological issues of truthfulness to ethical questions of effect. The capacity for reinterpretation admits the possibility of a conflict of interpretations. Nonetheless, a "philosophy of difference," Benjamin argues, is still philosophy (Benjamin, p. 178). Taking philosophy/theory (in)fidelity. There is no inside/outside to theory: theory/reinterpretation as the (im)possibility of translation.

Extending this line of specul(ariz)ation, on the imbrication of interpretation, difference, translation, I want to add another figure of difference, gender. The (im)possibility of gender as the (im)possible condition of translation. Gender, like translation a sign system, figures both "literally" and "figuratively" in this analysis. For gender may be constructed as a "naturalistic paradigm" establishing causal continuity among sex, gender and desire, or it may be understood as an "authenticexpressive paradigm" where some "true self" is revealed in sex, gender and desire (Butler, p. 22). On the other hand, gender may be shown to be produced within the presupposed binary categories as an effect of a history of practices and discourses. Indeed, this very instability calls into question the distinction between "literal" and "figurative," as it does a substantializing view of gender and, as I hope to show, of translation. Somewhere in this shifting terrain between trope (metaphor) and translation lies my subject. Despite their differing semantic fields there are overlaps in the connotations of the terms. One Greek term for translation is metapherein (another is hermeneuien). In Latin, both transferre and translatare are terms for all forms of metaphor as well 
as for the transfer of legal jurisdiction. Whether translation is a trope like metaphor, in which the vehicle is less important than the tenor (signifier less than signified) in a general movement of meaning, or whether what is carried across from the words of one language into another is transformed (signifier producing other signifiers/signifieds) is a point of debate in translation theory. Is translation a form of mediation or one of construction? Does it function within a regime of truth or in a regime of interpretation?

At stake is whether the word translation is understood in its general or restricted forms (Berman, p. 292). Within a restricted economy, translation is explored in its unique relationship to another text which gives it depth of signification as the reworking of a specific text within a specific context. Translation, then, engages with issues of the (re)covery of meaning. A general theory of translation, on the contrary, elaborates a theory of intercommunication from the horizon of translation. Translation in this case, like anthropology in Lévi-Strauss' analysis (Lévi-Strauss, 1967, p. 95), is "the system of systems, the one which permits the interpretation of the others" (Berman, p. 292). Any type of "change" in knowledge, in experience, as well as in aesthetics is understood to be translation: intercultural, interliterary, interlinguistic communication are all "carrying across." Under such a general theory, any activity of interpretation or rewriting (adaptation, literary criticism, book review, historiography, prefatory introduction, (Lefevere, p. 235)), as I have just tried to illustrate, any activity of doubling (metaphor, quotation, parody) may be considered "translation." This semantic and epistemic - expansion evacuates any specific meaning one may give to the term: translation becomes synonymous with the heterogeneity of the sign, always already read and translated, infinitely other. Translation in excess of interpretation. Living on.

\section{The circulation of signs/women}

In his Introduction to $A$ Theory of Semiotics, Umberto Eco argues that "theoretical research is a form of social practice" on the grounds that culture may be studied semiotically: "every [cultural] entity can become a semiotic phenomenon" becoming the interpretant of another sign-vehicle in the continuous process of communicative exchanges that is culture (Eco, pp. 28-29). Entities may have both symbolic value, as 
objects, and sign-values in a system of signification. The example Eco proposes is the "exchange of women." Women's symbolic value as objects (as bodies) puts them in opposition within the system to other women. When she enters into the system of kinship as a "wife," woman is "no longer merely a physical body: she is a sign which connotes a system of social obligations" (Eco, p. 26). What Eco advances as a presupposition of semiotics is the thesis of Claude Lévi-Strauss, so important to the development of both structuralism and feminism, that kinship is a structure through which men and women are positioned through complex systems of rules and rituals to be performed by each sex. Kinship systems are:

a kind of language, a set of processes permitting the establishment, between individuals and groups, of a certain type of communication. That the mediating factor, in this case, should be the women of the group, who are circulated between clans, lineages, or families, in place of the words of the group, which are circulated between individuals, does not at all change the fact that the essential aspect of the phenomenon is identitical in both cases. (Lévi-Strauss, 1967, p. 60)

Women circulating between groups — translating.

In elaborating the concept of woman as sign within a kinship system, Lévi-Strauss developed Saussure's hints for a semiology when he suggested that the system of differential relations along synchronic and diachronic axes he had outlined for the operation of linguistic signs could be generalized to other kinds of sign systems. For Saussure, "Language is a system of interdependent terms in which the value of each term results solely from the simultaneous presence of the others" (p. 114). Value of words lies in their "exchangeability," since words are interchanged with each other, but is also a measure of their difference. There are no positive terms, only relational ones (Saussure, p. 115). Value is not intrinsic or fixed, but is a function of positioning in a system of relational differences, where the value of a term is "determined by its environment" (Saussure, p. 116), established along paradigmatic and syntagmatic axes through operations of substitution and combination. In this, the senders and receivers of a signifier are part 
of the system and are constituted as speaking subjects in relation to each other and to the system through relations of exchange.

As Lévi-Strauss argues, kinship is a system producing woman as object of exchange that becomes a sign of the institution of culture. Situated within the kinship structures as not-men, women are "produced" as wife, mother, etc. Woman functions as "negative" difference in this system through the Oedipal complex and exogamy whereby difference is instituted and inscribed in the socio-symbolic order. Social existence is "the exchange of complementary values" (Lévi-Strauss, 1967, p. 61). The exchange is not simply the "communication of women": rather it is the putting in place of sexual relations and the institution of subjectivity through the prohibition of incest. Mother/son relations are regulated through this system by the introduction of a third term, either father or brother, to mediate and transform the symmetry considered to be the deathly impossibility of culture. To break up the circular nature of the biological pattern, the maternal uncle mediates between his brother-in-law and sister and between parents and child, on both vertical and horizontal levels. The kinship system establishes as meaningful oppositions patrilinear/avunculate. This "primordial law" is, according to Lacan, "identical with an order of language" (Lacan, p. 66) and superposes the order of culture over that of nature, instituting society. The incest taboo regulating mother/son relations is enacted through the law of exogamy.

Exchange - and consequently the rule of exogamy - is not simply that of goods exchanged. Exchange - and consequently the rule of exogamy that expresses it - has in itself $a$ social value. It provides the means of binding men together, and of superimposing [...] alliance governed by rule [...] [I]t provides the fundamental and immutable rule ensuring the existence of the group as a group. (Lévi-Strauss, 1969, pp. 480-481)

In contrast, to the restricted economy of endogamy which makes distinctions within a group, exogamy works towards "greater cohesion" (Lévi-Strauss, 1969, p. 481) by making distinctions between groups. 
What these laws establish are differential positions within a system, a form of identity through difference. Among the binary operations instituted are those of self/other, same/different figured in the semiotic field of the kinship system as endogamy/exogamy. For languages, the complementaries would be framed as native/foreign, though with two languages, the permutations of their interrelations are more complex (Lévi-Strauss, 1967, pp. 69-70). To conceive of the system, the one has to think of the other through the intermediary of a third (Lévi-Strauss, 1967, p. 74). It is the concept of reciprocity or general exchange which is "the most immediate form of integrating the opposition between the self and others" (Lévi-Strauss, 1967, p. 83). For reciprocity facilitates the synthesis of two contradictory chains (Levi-Strauss 1969, p. 490). As two types of systems of exchange of signs: "exogamy and language [...] have fundamentally the same function communication and integration with others" (Lévi-Strauss, 1969, p. 493). Indeed, integration is linked to the notion of reciprocity which functions in harmonious systems when oppositions will have been overcome, a utopian time that harkens back to a golden age "when the confusion of languages made words into common property, the latter describing the bliss of the hereafter as a heaven where women will no longer be exchanged" (Lévi-Strauss, 1969, p. 497). In Lévi-Strauss's account, women have been substituted for words in the venerable vision of an Adamic world with a universal language prior to Babel and the necessity for translation. Or some future speaking in tongues that would transcend the necessity of translation. That words and women be exchanged is a requirement of the emergence of symbolic thought as a means of "overcoming the contradiction" that woman poses as both object of desire, inciting proprietorial instincts, and subject of desire, binding others through alliances (Lévi-Strauss, 1969, p. 496). Unlike words that are wholly signs, however, woman is both sign and value (Lévi-Strauss, 1969, p. 496). Terms have value for both speaker and listener in the exchange (Lévi-Strauss, 1967, p. 61) in the case of woman who is both object and subject, both sign and producer of signs, caught up in a "split representation" (Lévi-Strauss, 1967, p. 61). Both within and without representation, woman threatens the system and necessitates the solution of exogamy and translation, "the exchange of complementary values," in order for circulation, for difference, as the fundamental possibility of culture as a social structure to be established. 


\section{Reconfiguring relations of the social contract}

In introducing woman as sign to solve this contradiction, Lévi-Strauss engendered another. While he overlooked it, feminists did not. Indeed, its initial critique by Simone de Beauvoir was an important stimulus for the orientation of contemporary feminist theory as a theory of difference, focusing on the binary oppositions masculine/feminine as they construct Woman. Exogamy is characterized by its having woman as its unique term of exchange. For this to happen, gendered division needed to have always already constituted women as the marked or valued term, a pre-given division that is itself social (Cowie, p. 126). This presupposed that men were inherently unsocial in their divisive desires and needed the exchange of women to institute sociality. In contradiction, it also presupposed that the social order is constituted by a reciprocal bond between men and men, not by one between men and women (de Beauvoir, p. 92). This is the point that Simone de Beauvoir emphasizes in her analysis of the history of women's oppression in The Second Sex. Little difference does it make whether social relations are organized along patrilineal or avuncular lines. Both organize relations of filiation. Women's position is the same, mediator not holder of the law, excluded from any autonomous relation in her structural situation as sign of alterity (de Beauvoir, p. 97). This position is not one of reciprocity, de Beauvoir continues, but of "fundamental asymmetry" where woman is either "contingent" or the worshipped/feared "Other," beyond or above the human realm (de Beauvoir, p. 91).

Two kinds of alterity are confounded here, so that as absolute Other, woman cannot be the other as subject in a relation of reciprocity. Indeed there is no reciprocity, no generalized exchange, only restricted exchange, under hierarchical relations. This primary sexual division inaugurating difference quickly becomes a system of deference. Difference is only an illusion, since reciprocal relations are in-different. There is no reversible subjectivity between women and men. The duality in the collectivity is not complementary, for what are opposed in the system are two groups of men. "Society has always been masculine, political power has always been in men's hands" (de Beauvoir, p. 91). They affirm their transcendence in opposition to women situated as Other. The rule of exogamy aids in this domination of the powerful archaic Earthmother and the assertion of the human, the 
social, over the magic (de Beauvoir, p. 96). Mapping Lévi-Strauss' model of the social order onto Hegel's account of the reciprocal relations of intersubjectivity fixed in oppression by the Master/slave dialectic, de Beauvoir concludes that Woman as constructed in the kinship system is alienated, contingent, inauthentic. Whereas in other power relations there is reciprocity between colonizer and colonized, there is no reversibility, no reciprocity, no commutability between gendered subject and object (de Beauvoir, p. 18). Borrowing from Lévi-Strauss's structuralist theory to consider sexual difference as a system of complementary values, de Beauvoir sets out to analyze why the passage from Nature to Culture through the formulation of systems of oppositions - duality, alternation, opposition, symmetry - has produced only fixed, hierarchical difference constructing a singular, masculine subject.

\section{The traffic in women}

It is just this critique of phallocentrism as fixed and restricted, rather than a reciprocal or general system of relations of exchange, that Irigaray takes up in her exploration of "hom(m)o-sexuality," that is, the social bonding between men that is the differentiating moment of social exchange which paradoxically takes place through the heterosexual distribution of women. This phallogocentric economy depends on an economy of reciprocal difference that is never manifest in what is an order of in-difference, an order of the same. Offering a critical exegesis of how the non-reciprocity between the sexes that is presupposed in the exchange between men is inarticulable within that economy, she considers what might happen if "the goods get together" ("Les marchandises entre elles") (Irigaray, 1985b). Rather than exploring the subjectivities produced when women are forced against their will to participate in the violence of the social order founded on a sacrificial contract, the killing of the archaic (pre-Oedipal) mother, as Julia Kristeva has done, especially in her study of abjection, Irigaray has taken up Simone de Beauvoir's concern that the gendered socio-symbolic order produced by exogamy fails to constitute women in the plural as a group (de Beauvoir 92). Irigaray's work is an attempt to performatively stage the inarticulate presuppositions and the unnameability of the feminine in an alternate economy of relations. 
This engages the post-structuralist critique of the identitarian structures of exchange of Saussure and Lévi-Strauss, where the relating and unifying movement within a totalizing field of signification suppresses the moment of difference, of arbitrariness, through the fixity of binary oppositions that confine the ambiguity of linguistic (and cultural) signification. Irigaray's project attacks the totalization of the neutral, the universal, the in-different, in favour of an active field of differential interrelations. As she writes in Sexes et parentés: "Comment remodeler les langages existants pour donner lieu a une culture sexuée? C'est l'enjeu de mes recherches" (Irigaray, 1987, p. 196). Differences are necessary to produce a dynamic field, however, in the present situation, she concludes, there is only one gender not two: "Au lieu de se reconnaître réellement deux genres et d'accepter une révélation venant de l'autre genre - révélation en soi et pour soi - , le peuple des hommes prétend détenir toute la vérité et le droit de légiférer en tout: philosophie, droit, politique, religion, science [...]" (Irigaray, 1987, p. 128). Analysis of the social imaginary and the symbolic order is in the mode of reproduction of the existing order, not in that of creation, and this is the case for all "strategies of reading, translation, interpretation" (Irigaray, 1987, p. 101, my translation). The impact of discursive structures on meaning is ignored in "discussions about content which fail to consider the vehicle of the message" (Irigaray, 1987, p. 183): concern is focused on the signified, on similarity and the axis of substitution, not on the signifier, and relations of contiguity along the axis of combination.

But to effect permanent and profound changes in these practices - indeed in "social relations, language, art" - "the economic system of exchanges" must be transformed (Irigaray, 1987, p. 96). In the current economy, an anal economy, women exchange their children for the status of commodity, for value in the marketplace through the "maternal function" (Irigaray, 1987, pp. 98-99). Castrated and contained by this "libidinal economy," they submit to its "economic, imaginary and symbolic organization" (Irigaray, 1987, p. 98). Sexual difference is held captive by the Same. In order to transform these relations, so that women will no longer be "objects of use and exchange among men," will no longer "be rivals on the marketplace," it is necessary to explore women's relationships in the plural through the singularity of women's love for other women. This would image a different economy of 
relations through a different organization of desire than the current economy of desire between men. There is a difference, Irigaray maintains, between the archaic love for the pre-Oedipal mother and love for one's sisters. What is needed for this is a symbolic order valorizing a heterogeneous economy that allows for bonding between women as a group (Irigaray, 1987, p. 32). The "order of the same," an economy of "monopoly" (Irigaray, 1985b, pp. 73-74), would be replaced by an order of heterogeneity, "an economy of abundance" (Irigaray, 1985b, p. 197).

That Irigaray has extended her examination of economies of exchange to the sacred and monetary systems in her recent work, Sexes et parentés (Sex and Kinship), is evidence of the centrality of her concern with systems of relations in her critique of the socio-symbolic order, whose totality and closure is both presumed and contested in her work. Against the containing and immobilizing categories of the current symbolic order with its monopolistic claims to totalize all possibilities of exchange, she images a generalized exchange that is not conceivable within the order of the Same. In so doing, she undermines the totalizing claims of the discourse, to expose the Symbolic as "hegemonic" (Butler, p. 41).

How can we speak so as to escape from their compartments, their schemas, their distinctions and oppositions: virginal/deflowered, pure/impure, innocent/experienced [...] How can we shake off the chain of these terms, free ourselves from their categories, rid ourselves of their names? Disengage ourselves, alive, from their concepts? Without reserve, without the immaculate whiteness that shores up their systems. You know that we are never completed, but that we only embrace ourselves whole. That one after another, parts - of the body, of space, of time - interrupt the flow of our blood. Paralyze, petrify, immobilize us. (Irigaray, 1985b, p. 212)

In this regime of truth, within the logic of truth, of being (Irigaray, 1985b, p. 86), a woman is encoded as "awoman," as "an-archic," "a-teleological", "a body-matter marked by their signifiers, a property for their souls-fantasies" (Irigaray, 1985b, p. 96). She is the place - at once origin and vanishing point - where, paradoxically, 
"their encoding as speaking subjects is inscribed and where the 'objects' of their desire are projected" (Irigaray, 1985b, p. 96). "Surplus value" has to do with the body of the Other. "That is for the Subject, an over-pleasure of what instates it as a speaking being" (Irigaray, 1985b, p. 93). Sexual pleasure is situated in the body of the Other and is "produced" because the Other exceeds the grasp of discourse (Irigaray, 1985 b, p. 97). But the Other has no other, produces no value, no pleasure. Woman is the Phallus, though man has it. This entails a paradox, however, one operative in all the discursive systems of the order of the Same: female sexualization is produced as a logical requirement of this order's binary oppositions and of the existence "of a language transcendent with respect to bndies" that is nonetheless required to become incarnate "'so to speak'." Woman is constituted as a potentially disruptive pre-discursive reality by a language and symbolic order that "rules as master" (Irigaray, 1985b, p. 89). Within this order, all that may be considered is the signified (the meaning) or value in the exchange and not the signifier (the vehicle) or process of exchange (the production of meaning).

It is this inability to conceptualize a relation to the instance of enunciation of signs and to the tenor of the metaphors of philosophical discourse, that is, to conceptualize a relation to the process of production of this discourse which consequently seems self-sustaining, dis-embodied, that Irigaray deconstructs in Speculum through her analysis of the Platonic metaphor of the cave. The focus on the light of the transcendent signified, the logos, blinds Plato to the topology of the cave itself where the process is taking place in the "antre" (cave), and to the implications of the metaphors of birthing he deploys to describe the production of the philosopher-ruler who will emerge from the cave by a passage - way ("entre") that resembles a birth canal. His overlooking this process or passage, of focusing on Being instead of Becoming, results in a metaphysics valorizing the one, the same, that makes of the "antre" an enclosure instead of a process ("entre"). The "enceinte" functions as a containing wall rather than as a womb-like space of creation and transformation. It is a system of reproduction, repetition, of likeness, of the "propre" - logocentrism — not a system of interrelations. Phallocentrism too operates in the logic of the Same in what Irigaray exposes as an a priori contradicting the very system it subtends. This economy and ideology of reproduction values the 
maternal function over the erotic: mother-daughter relations are conceived in terms of masculine desire and homosexuality (Irigaray, 1985a, p. 63), that is within the inscription of "property," to submit to the name (law) of the father.

Enveloped in proper skins, but not our own. Withdrawn into proper names, violated by them. Not yours, not mine. We don't have any. We change names as men exchange us, as they use us, use us up. It would be frivolous of us, exchanged by them, to be so changeable. (Irigaray, 1985b, p. 205)

In this probing of the logical paradoxes on which this system of the Same is (un)founded, Irigaray strategically performs the mobility and difference that this order of the same cannot represent. She exposes the instability of the system of property established to keep woman in her proper place as an object of exchange. But this very exchangeability of the sign introduces considerations of indeterminacy and contingency that undermine the totalizing claims of this phallic economy, this order in which the masculine has a monopoly on the same, a monopoly on value (Irigaray $1985 \mathrm{~b}, \mathrm{p} .73$ ). As her deconstructive probing of the metaphors of this economy enacts, sameness, unity, the phallus, involve giving an "a priori value to Sameness," the category that is at once the centre of this system and what is excluded from its reflection or representation. Resorting to "time-honoured devices such as analogy, comparison, symmetry, dichotomous oppositions," the system remains emprisoned in a "certain economy of the logos" that produces in-difference. Despite this, as Irigaray shows, the "enceinte" is broken open the categories that aim to fix and contain difference are mined by anoriginal differance. By stressing the overdetermination, the logical contradiction, the polysemy, the deferred meaning, the repetition compulsion, the death drive, in this system, Irigaray makes manifest the presuppositions of the scene of representation, the "indifference that subtends it assur[ing] its coherence and its closure" (Irigaray, 1985b, p. 72). In-difference, it is both the same, likeness, but only as difference: this radical indeterminacy precludes any identity. Yet another paradox. 


\section{Contamination}

The "interpretive lever" Irigaray introduces into this scene for its unfolding is a strategy of "interpretive re-reading," reading not to produce "symbolic, point-by-point interpretation of philosophers' utterances," but instead to examine "the operation of the 'grammar' of each figure of discourse, its syntactic laws or requirements, its imaginary configurations, its metaphoric networks," and also to probe "its silences" (Irigaray, 1985b, p. 75). It is a reading not for meaning but to unfold the processes of meaning making, to follow along the chains of signifiers to locate the overdeterminations operative in their combinations. Repeating the philosophers' utterances, it is a reading with (and against) the text. Touching on. Living on.

This engages in another economy of sign manipulation, not that of the proper, but of the (im)proper, of contamination. An economy not of penury, of usure, but of "abundance." Not of containment but of discharge, where one thing flows into another, touches upon another.

And don't worry about the 'right' word. There isn't any. No truth between our lips. There is room enough for everything to exist. Everything is worth exchanging, nothing is privileged, nothing is refused. Exchange? Everything is exchanged, yet there are no transactions. Between us, there are no proprietors, no purchasers, no determinable objects, no prices. Our bodies are nourished by our mutual pleasure. Our abundance is inexhaustible: it knows neither want nor plenty. Since we give each other (our) all, with nothing held back, nothing hoarded, our exchanges are without terms, without end. How can I say it? The language we know is so limited... You are moving. You never stay still. You never stay. You never 'are.' How can I say 'you,' when you are always other? How can I speak to you? You remain in flux, never congealing or solidifying. What will make that current flow into words? It is multiple, devoid of causes, meanings, simple qualities. Yet it cannot be decomposed. These movements cannot be described as the passage from a beginning to an end. These rivers flow into no single, definitive sea [...] This unceasing mobility. (Irigaray, 1985b, pp. 214-215) 
Through the strategic use of metonymy figuring a provisional counter-discourse, through questions, the scrambling of deixis (We you/I), Irigaray configures a discourse that flows through the grids and closures of the discourse of the Same, exceeding its grasp. This is a discourse of women to women, beyond that regulated by the "signs of possession" (Irigaray, 1985b, p. 211), one that simulates the pleasure of women touching each other, touching on, living on. ("When I touch myself, I touch you at a distance"). This is a "dialect of relation" not sexualized only by the phallic function, that is, the maternal function as the signifier of the desire of the Other (Irigaray, 1985a, 1985b, p. 62). Nonetheless, though this culture makes of women "a medium of exchange, with very little profit to them" except in the power of slaves, this is not a discourse that simply reverses the relation of mastery, but one that deconstructs the very concept of mastery and identity, of totality and closure, emerging from the decentred subjectivity of one who is always contradictory and multiple, as an exploration of heterogeneous "auto-eroticism" (Irigaray, 1985b, p. 32).

Hers are contradictory words, somewhat mad from the standpoint of reason, inaudible for whoever listens to them with ready-made grids, with a fully elaborated code in hand. For in what she says, too, at least when she dares, woman is constantly touching herself $[. .$.$] For if "she" says something, it$ is not, it is no longer, identical with what she means. What she says is never identical with anything, moreover; rather, it is contiguous. It touches (upon). And when it strays too far from that proximity, she breaks off and starts over at "zero" [...] (Irigaray, 1985b, p. 29)

This is not conservation through the reproduction of self, of meaning. On the contrary, the woman aims to get rid of words so as not to become fixed or congealed in them. It is a loss of meaning that cannot be called negativity in the philosophical order, but is a non-sense that is beyond the closure or horizon of absolute knowledge, beyond the alternatives of symmetry or opposition, outside the closure of metaphysics as non-value, exceeding the logos in thinking the unthinkable (the lesbian couple). The "parole blanche" of a general economy of writing, it might be called, in Derrida's words: "a sort of potlatch of signs." (Derrida, 1967, p. 403). This is to participate in an economy of 
expenditure without reserve, exceeding the law, an economy of the gift whose contract entails a ritual of sacrifice (Mauss, p. 13), of usure.

\section{The goods get together}

What is at stake for Irigaray is a different economy, one that "upsets the linearity of a project, undermines the goal-object of a desire, diffuses the polarization toward a single pleasure, disconcerts fidelity to a single discourse..." (In)fidelity - the excess or waste of a "mirror invested by the masculine 'subject' to reflect himself, to copy himself" in "specula(riza)tion" (Irigaray, 1985b, p. 30). This imaginary, staged as hypothetical figuration of a feminine libidinal economy organized otherwise around the endless circulation of desire, of signs, is articulated "behind the screen of representation," outside the reach of screen memories of a primal Oedipal scenario, in the repetition of a repetition of Souter's version of Alice through the Looking Glass. This is the order of the recursive paradigm, of the anamorphic distorting mirror. Like the Speculum, it refuses to send back a copy in reverse, but scatters and disperses the light rays, producing a different image, an image of différance. In its framing, Irigaray's meditation on "This Sex Which is Not One" - not an identity or an entity, but a moveable site ("'She' is indefinitely other in herself," Irigaray, 1985b, p. 28) - plays out indeterminacy, shifting between plurality and lack. The paradox of deferred meaning can only be performed, not described. The text enacts the topological logic it discerns, eschewing "ownership and property," but not nearness. Topological relations of proximity organize an economy that refuses fixity and identity: "Nearness so pronounced that it makes all discrimination of identity, and thus all forms of property, impossible." This disrupts all prevailing economies, especially that in which woman has been a "use-value for man, an exchange value among men" (Irigaray, 1985b, p. 31). The "commodity" is not a commodity, not an entity, but a process and, as such, slips through the "competition for possession" (Irigaray, 1985b, p. 32). This would bring an end to the "traffic in women" since they are no longer commodities in that they refuse to go to market.

The disruption produced by the "commodities among themselves" (or "the goods getting together") brings to a crisis the aporia on which the social contract has been figured, namely its sexual in-diffe- 
rence. The focus on exogamy as the rite of passage from Nature to Culture has served "as an alibi for the smooth working of man's relations with himself," that is, for endogamy. "Sociocultural endogamy" excludes the participation of woman, the other, for women are forbidden commerce with other women. "The use and traffic in women subtend and uphold the reign of masculine hom(m)o-sexuality, even while they maintain that hom(m)o-sexuality in speculation, mirror games, identifications, and more or less rivalrous appropriations, which defer its real practice" (Irigaray, 1985b, p. 172). Men make commerce of not with women, for the economic relations in place require women to alienate themselves in exchanges in which they do not take part and exempt men from being circulated as commodities. Irigaray's re-writing exposes the conflation of sign and symbol, destabilizing the claims to purity of the discourse of the same. The commodities among themselves are neither equal, nor alike, nor different, for they have relation only in the desire of the subject whose narcissism endows the commodities with value. But this is, as Irigaray writes, to add a plus value or "supplement" to the commodity, a supplement found in another commodity, whose use value then becomes the standard value (Irigaray, 1985b, p. 177). Women-as-commodities are divided within themselves into use-value and plus or exchange value, into matter-body and the precious supplement that is ungraspable by themselves. This is a division into private and social use (Irigaray, 1985b, p. 176). Probing here the "split representation" of woman within and without representation, the contradiction Lévi-Strauss attempted to resolve with the theory of the traffic in women, Irigaray on the contrary exposes it as an a priori necessity of a phallic economy. In that the labour force expended in the production of an object is abstracted in the process of universalization that is the operation of social exchanges, women's role is as "fetish-objects" in respect to the Phallus which they represent, rather than have (Irigaray, 1985b, p. 183). "Naturally," women remain amorphous: socially they are produced by the phallic economy as "mother, virgin, prostitute" (Irigaray, 1985b, p. 186). In this, man appropriates the reproductive capacity of woman "marked with the name of the father" and "engenders himself as a man, born into "human," "supematural" existence. The resulting social system, as Irigaray writes, "can be interpreted as the practical realization of the meta-physical" (Irigaray, $1985 \mathrm{~b}, \mathrm{p} .189$ ), an idealized order that disregards the contingencies of the sign materialized in an instance of enunciation. It is an order of 
phallogocentrism that exalts the Phallus as "Woman" but distances it from any connection to the penis.

When the "goods get together," they "short-circuit the mechanisms of commerce" and "expose what is really at stake" by "lowering the sublime value of the standard," that is, unmasking the power of the phallus by showing the penis to be merely a means to pleasure among men (Irigaray, 1985b, p. 193). The penis is introduced in a deflationary gesture to expose the overdeterminations of the metaphor, destabilizing the distinctions between "figurative" and "literal" meaning on which phallocentrism is founded. This brings to a crisis the illusions, the representations, that have functioned as screens "pretense or sham" for a system that hides "its own endogamies" (Irigaray, 1985b, p. 192). The word signifies beyond itself, bearing within it the contradictions marking a tradition: exogamy (of Lévi-Strauss's sort) is not really exogamy but endogamy. The very order of heterosexuality requires homosexuality as its organizing principle. Yet, such relations among men can take place only on the symbolic level: to display pederastic love would bring the symbolic system of monogamous reproduction to an end by destabilizing its instituting categories. Exchanges and relationships among men are thus paradoxically both "required and forbidden by law" (Irigaray, 1985b, p. 193).

Feminine homosexuality cannot be accounted for in this system, for as soon as a woman desires herself, speaks to/for herself, she is a man. Any relationship with another woman is a homosexual, and consequently masculine, one by virtue of the "masculinity complex" (Irigaray, 1985b, p. 194). Female homosexuality can only be configured by masculine desire in the order of the same through the Phallus. There is no place in the symbolic order to figure the relations of motherdaughter. This is the "blind spot of an old dream of symmetry" (Irigaray, 1985a, p. 11). There are no reciprocal relations here: only one kind of endogamy can be sustained. Yet this is done through a metaphor wherein endogamy presents itself as difference, as exogamy. If the goods refuse to go to market, however, attempt to maintain a "commerce among themselves," they undermine the logic of identity by bringing to a crisis the contradiction between use-value and exchange-value in the restricted economy. Foregrounding the blurring of Phallus/penis, they would expose the metaphor that is not a metaphor 
but a metonymy. In this gesture of interruption and dis/placement, they enact an order of exchange not ruled by the either/or of binary oppositions, but by the and/and of contiguous chains.

Exchanges without identifiable terms, without accounts, without end... Without additions and accumulations, one plus one, woman after woman... Without sequence or number. Without standard or yardstick. Red blood and sham would no longer be differentiated by deceptive envelopes concealing their worth. Use and exchange would be indistinguishable. The greatest value would be at the same time the least kept in reserve. Nature's resources would be expended without depletion, exchanged without labor, freely given, exempt from masculine transactions: enjoyment without a fee, well-being without pain, pleasure without possession. As for all the strategies and savings, the appropriations tantamount to theft and rape, the laborious accumulation of capital, how ironic all that would be. (Irigaray, 1985b, p. 197)

This Utopian fiction is figured as an economy of excess which undermines the economy of the same that has maintained incest in the realm of pretense, as a necessary fiction.

In developing this model of an alternative economy of signification, Irigaray, does not collapse the feminine into the female in order to undermine stable binary sex oppositions between men and women with a theory of bi-sexuality as Hélène Cixous has done (Binhammer, p. 77). Rather, the collapsing of the distinction between phallus/penis under the either/or logic of the same, works to displace oppositional thinking by associative thinking that works with the contingent, so that though never fixed, there is nonetheless a connection between the masculine and the male and between the feminine and the female. Asking the question "What is woman?" leads only to the answer "lack" or "imitation." The feminine signifies possibly as "disruptive excess" (Irigaray, 1985b, p. 78). To approach the feminine as a style that is not a style, is to explore a way of looking at things that does not privilege sight, distinctions, but the "tactile" which puts things back in touch with themselves without constituting any unity. Desiring "the proximate," rather than "(the) property," its motifs of "self-touching" and "proximi- 
ty" cannot "appropriate the feminine for discourse." This way of working with words involves "simultaneity" - "its proper aspect" that is never fixed in the "identity-of-self of some form." It is "fluid," exhibiting those characteristics of fluids that create dynamics, "those rubbings between two infinitely near neighbours" (Irigaray 1985b, 79). Not the loss of erasure, but the excess of touching on.

\section{An economy of fluids}

Fluidity is connected to female bodies metonymically in "When Our Lips Speak Together," ("We know the contours of our bodies well enough to love fluidity"; Irigaray, 1985b, p. 215) in what Jane Gallop has called Irigaray's "vulvomorphic" display (Gallop, p. 96). Fluidity is what is most taboo in the exchange between men, as is demonstrated in Irigaray's parodic rewriting of de Sade, "'Françaises', ne faites plus un effort..." How to figure the "real" female body in the pornographic paradigm? For the libertine, flouting all prohibitions, "menstrual blood generally remains taboo. Excrement may be all right, but menstrual flow, no..." (Irigaray, 1985b, p. 200). Fluidity may be a motif irreducible to any centring, but its connections to the female body stage a reverse collapsing of boundaries. Can the literal be divorced from the figurative? Is it possible to empty out all meaning from feminine that relates to the referent of female bodies? Irigaray suggests the impossibility of such binary oppositions in her description of the work on language that must be undertaken to decentre the masculine from its totalizing claims, so that "the masculine would no longer be 'everything'" (Irigaray, 1985b, p. 80). What must be disrupted is the "teleological effect" that makes "linear reading" possible and supports common sense understandings of unary processes. In a process of constant "redoubling," continuous reversal, every separation, including that between the instance of enunciation and the utterance would be turned topsy-turvy. Binary "recto-verso" structures would be displaced should the retroactive impact of the ordering of sentences on the beginning of an utterance be taken into consideration. In such a logic, it is impossible to separate the female from the feminine, the literal from the figurative, for they are constantly touching and retouching upon each other "in the supplementarity of this reversal" (Irigaray, 1985b, p. 80). 
In this, the "opposition between structures of horizontality and verticality" at work in language is also displaced so that the vertical collapses into the horizontal. No longer is it possible to separate the operations of substitution, carried out along the paradigmatic axis of the system, from those of combination carried out along the syntagmatic chain. The relations of signifier to signified in the first are mixed up with the combination of signifiers and the particularities of the speech act in the second. What Irigaray displaces here is the binary opposition of the two systems of relation established by Roman Jakobson, when he linked them to the operations of figurative language by relating the faculty of selection and substitution to metaphor and that of continguity and combination to metonymy. The binary opposition of the two tropes is also supported by Jacques Lacan who, in "The Agency of the Letter in the Unconscious," reworks Jakobson's distinction in psychoanalytic terms, so that the field of metaphor corresponds to the Freudian concept of condensation while metonymy is connected with displacement. Lacan develops an algorithm for metaphor where the + sign, placed between $S(+)$ s, manifests the crossing of the bar dividing the signifier from the significd, to produce a signification effect which is of creation (Lacan, p. 274). Irigaray critiques the phallocentrism of Lacanian psychoanalysis, underlining the tendency of metaphor to rigidify the slippage of signifiers, through an analysis of the work of metonymy in an essay on "The 'Mechanics' of Fluids." This critique of the discourses of psychoanalysis, philosophy, and their construction of gender, centres on their shared modalities of exchange and signification. Through metaphor, it will lead us back to the (im)possibility of translation.

What is at stake in this essay is the need for the "liberation of women" which necessitates a transformation of the economy through a change in culture and language. Entailed in this change in economies is a shift in the "ruling symbolics" from a "mechanics of solids alone" to an "economy of fluids" (Irigaray, 1985b, pp. 105-107). Noting the long-standing "complicity" between rationality and a mechanics of solids, Irigaray interrogates logical rules such as the principle of equivalence which holds that whatever is non-identical to itself is a contradictory concept and the focus of Lacanian psychoanalysis on "le petit objet a." What, she asks, is there in the structuration of (the) language that has maintained a focus on the "definition of terms" 
instead of on "the analysis of relations among terms" (Irigaray, 1985b, p. 107)? Why has there been a focus on relations of signifier/signified to fix a singular meaning rather than on relations among signifiers to explore the overdeterminations that produce meaning? The ruling mode of symbolization, having excluded the properties of fluids, has "privilege[d] metaphor (a quasi solid) over metonymy (which much more closely allied to fluids" (Irigaray, 1985b, p. 108). In psychoanalysis, this has resulted in the "object of desire" being "the transformation of fluid to solid" (Irigaray, 1985b, p. 111) and the consequent privileging of the phallus. In logic, a preponderant role is left to "the symbol of universality" (Irigaray, 1985b, p. 106) which, privileging the principle of equivalence and analogy over paradox and combination, excludes the possibility of there being several contradictory systems modulating the order of truths. Interrelations among concepts are subsumed by the all which is the extension of the concepts. The not-all, "God or feminine pleasure" is the "geometric prop," the "copulative link" - "awoman" (Irigaray, 1985b, pp. 106-107). But this copula in the logic of Being has been appropriated in advance for a project of formalization, mathematization or idealization.

"An adjustment of meaning," a parallax, is required for analysis of the properties of fluids. From the perspective of the economy of solids, of the proper, woman is unrepresentable, lack or excess. In discourse, she does not exist: "And yet the woman-thing speaks. But not 'like,' not 'the same,' not 'identical with itself' nor to any $x$, etc. Not a 'subject,' unless transformed by phallocratism. It speaks 'fluid,' even in paralytic undersides of that economy." (Irigaray, 1985b, p. 111) Situated in the dynamics of the near, in resistance to the countable, she is easily traversed by flow, mixing and diluting with bodies in like state: "What she emits is flowing, fluctuating, Blurring. And she is not listened to, unless proper meaning (meaning of the proper) is lost" (Irigaray, 1985b, p. 112).

The flow is frozen and congealed by rationality since the fluid "is by nature, unstable" like the "inside/outside of philosophical discourse" (Irigaray, 1985b, p. 112), an instability or indeterminacy that invades language too, against which the geometrism of the order of solids defends by denying the metaphoricity of all language and by constructing binary oppositions between metaphor and metonymy. This 
is a binary that Irigaray destabilizes in the logic of paradox that is the logic of metonymy. It is impossible to step outside the symbolic order: one is caught up in the metaphoricity of language. But the question of inside/outside is itself an unstable relation, grounded in the binary logic of the same. Within the logic of abundance (of the parergon or frame), they perform as relational terms producing their opposites since they are mutually constitutive, touching on each other. In addressing the status of philosophical discourse and exposing the fictive and provisional nature of its truths in order to explore the possibilities for a logic of becoming, Irigaray restages an argument of Derrida's - with a difference, that of deliberately assumed mimicry.

\section{Metonymy in the text of philosophy}

"Metaphor in the text of philosophy" (Derrida, 1982, p. 209) is a major issue in contemporary French philosophy. In "White Mythologies," Derrida probes the slippage of boundaries between "natural language" and "philosophical" language through the status of metaphor in philosophical discourse. In the tradition of metaphysics, there is an attempt to divorce truth from metaphor. Derrida argues that while philosophical discourse asserts a truth outside metaphor, and attempts to resist any contamination of figurative language, it cannot do so: philosophy can never escape metaphor. Metaphor promises more than it gives and so functions as a performative. In terms of truth, however, it is not profitable, it leads to a loss. What interests him is the "usure of metaphorical force in philosophical interchange" (Derrida, 1982, p. 209). Usure constitutes the very history and structure of the philosophical metaphor: "it will never make a profit" because even if one sought to circumscribe all metaphors in philosophy, "one metaphor, at least, always would remain excluded, outside the system [...] the metaphor of metaphor" (Derrida, 1982, pp. 219-220). The concept of metaphor is thus inscribed in the general economy of writing, an economy which, according to Derrida, is the one that shows how metaphysics's eternal attempt to profit from its ventures is based upon an "expenditure without reserve" without which there could be no idea of profit (Derrida, 1982, p. 209). 
Usure, as he comments, has a double import, both the supplementary product of a capital, the surplus valued from linguistic exchange - a self-cancelling term - and erasure by rubbing. Metaphor too is double, that which simultaneously hides and is hidden, an "original figure" that both effaces itself and is ef-faced (Derrida, 1982, p. 211). A kind of "transparent figure," equivalent to a literal meaning, becomes metaphorical when philosophical discourse puts it into circulation. The first meaning and the first displacement are simultaneously forgotten, the metaphor is no longer noticed and is taken for the proper meaning. Philosophy, Derrida asserts," "would be this process of metaphorization" (Derrida, 1982, p. 211). This "unlimited [linguistic] surplus-value," the absolute usure of the sign" is not an issue with the metaphysician: the "fabulous" scene of the production of the metaphor has been erased, though it remains "as white ink," active if invisible under a palimpsest.

Metaphor has traditionally been defined as a trope of resemblance, not just as resemblance between a signifier and signified, but also the resemblance between signs, one of which represents the other. Derrida sets out to show that it is also a trope of difference. Stress on the analogical powers of metaphor develops from a concern with "semantic depth" and an attention to the vertical axis of subordination, rather than as he proposes, to the "positional combinations" along the "metonymic axis," that is to the value of the term as determined by its environment. A project in metaphorics is an (im)possibility, Derrida writes, in light of the dissemination of the "fantasmagoric" sun in Mallarme's texts which disrupt the oppositions of literal [propre] and figurative, metaphor and metonymy, figure and ground, syntax and semantics. Philosophy, though, can perceive its metaphorics "only around a blind spot," unable to grasp the metaphor of metaphors because of the fundamental oppositions of sensible/intelligible, signifier/signified that have been constituted as the history of philosophy by tropological movements no longer perceived as metaphors, functioning as catachresis (Derrida, 1982, p. 229). Philosophical discourse is constituted by metaphorics in a system of interpretation that links metaphor, mimesis, logos, physis, phone, semainein, onoma (Derrida, 1982 , p. 232). Attempting to restore movement to the chain of signification, Derrida rereads the treatises on rhetoric, rereads Aristotle's Poetics to situate metaphor within the formulation of the concept of 
mimesis. For Aristotle, "to produce a good metaphor is to see a likeness" (1459 a 7-8). The condition for a good metaphor is thus the condition for truth. Mimesis is considered to belong to logos. In contrast, according to Aristotle, is the animal aping or "gesticular mimicry" of the unthinking beast. In this very definition of mimesis as that which is the privileged action of man, the physical impinges as the very "naturalness" of the movement that "constrains mimesis" in its redoubling (Derrida, 1982, p. 237).

The contamination of the metaphysical by the physical through the work of a metaphor that is not perceived as a metaphor is what Luce Irigaray disseminates in Plato's analysis of mimesis and truth in the metaphor of the sun and the cave. For her too, the issue is philosophy's relation to language and the impossibility of divorcing the figurative from the literal or truth from metaphor, that is truth from fiction or interpretation. However, she has another project in this critique of metaphysics, one focused on the question of gender. Unlike Derrida, she is not preeminently concerned with the metaphor of the sun, but rather with that of the ground from which the sun is viewed, the metaphors of location that situate the viewer within a specific site determinant of the semantic depth of his encounter with the sun of truth. Pursuing this politics of location, Irigaray demonstrates that the metaphors in play are gendered metaphors. The economy of usure is at work in Plato's metaphor: while he argues against metaphor as a bad copy of the Ideal, the mode of his argument consists, itself, of metaphors, specifically of the metaphor of the cave/womb/woman. Irigaray does not follow up Derrida's line of argumentation to pursue the question of the difference between good and bad metaphors, as they function in science, though she deploys this analysis in her own strategy of interpretive rereading. While dead metaphors or catachresis are bad metaphors, those that form the presupposition of arguments, a "nonmediate, constructed metaphor, is useful when it comes to 'illustrate' knowledge wrested from bad metaphors." Its value is "blanching" (Derrida, 1982, p. 259). A self-reflexive use of metaphor that deploys metonymy strategically working out the exchange between tenor and vehicle so as to foreground the work of the vehicle is what Irigaray enacts in her "vulvomorphic" connections "when our lips speak together" (Irigaray, 1985b). This self-reflexive troping that foregrounds the fictiveness of its strategies performs its own work of deconstructing 
the unstable boundaries between truth and interpretation and, as Irigaray makes clear, develops site specific metaphors contingent on the gender of the fabular philosopher to show that the Phallus connects to a penis. However, she also disrupts the metaphoric forces of the cave/womb/woman equation by destabilizing its fixity through the polysemic play on "antre" (cave)/"entre" (between) to foreground the philosopher's cave as a place of passage, a site of transformation and becoming, not the ground of being.

In developing such a site specific or contingent theory of value, Irigaray foregrounds the issue of mimesis and mimicry in Plato's work. The metaphors she deploys are not metaphors but metonymies, flowing, fluid, running together. The metonymic field is that organized by relations of contiguity and combination, not of similarity and substitution. Consequently, it escapes from the either/or formulation that separates tenor and vehicle, intelligible and sensible, form and matter, signs and bodies. It is no longer possible to read the relation of feminine to female, of woman to women literally - biologistically or metaphorically as having no connection to women. Rather the literal and the figurative run into each other, contaminating each other. The value of the terms is determined by their environment, metonymically considered in relation to what touches them. Following up the signifying chain from metonymy to metonymy leads one from the "fluid," from the female/feminine to the issue of reproduction to mimesis.

the ebb and flow of our lives spent in the exhausting labor of copying, miming. Dedicated to reproducing - that sameness in which we have remained for centuries, as the other. (Irigaray, 1985b, p. 207)

Mimetism as production, a heterogeneous logic of becoming, displaces mimesis or the reproduction of the proper. As Irigaray phrases this, the place of the feminine in the symbolic order, the only one assigned her, is that of "mimicry" (Irigaray, 1985b, p. 76). The feminine, then, is a role that must be "assumed deliberately." This is the "gesticular mimicry" or animal aping of the anti-logos productive of bad metaphor, according to Aristotle. "To play with mimesis is thus for a woman to try to recover the place of her exploitation by discourse without 
allowing herself to be reduced to it." This already changes a form of subordination into affirmation and challenges the binary idea/matter, tenor/vehicle, literal/figural, crucial to mimetic theory. Through this "playful repetition," through this performance of the feminine, taking femininity (in)fidelity, what was supposed to remain invisible - the work of troping - is exposed. Simultaneously, that women are such good "mimics," "unveils" the fact that they are not completely caught up in this function, but also "remain elsewhere" (Irigaray, 1985b, p. 76). Femininity is consequently a provisional performance, not an essence.

In developing such a theory of value based on change, on the metonymical trait of language and the constant slippage and rubbing of signifier on signifier at a loss, rather than on symbolic value of exchange, Irigaray foregrounds the problem of mimesis and mimicry in Plato's work. Through her exploration of the metaphor of the cave through which Plato develops his theory of ideas and the inadequacy of any material reproduction of them, Irigaray shows how Plato's argument is contaminated by mimesis technè, material mimesis or reproduction that produces distortion, and fails to maintain the binary opposition between intelligible (mathematical and logical relations) and sensory mimesis, philosophy and rhetoric (art), original and copy, metaphor and metonymy, his argument had set out. Consequently, the distinction between mimesis and mimicry is undermined when they run into each other. Promising more than it gives, philosophy is a performative. Gender and translation participate in this economy of contamination, unable to maintain a separation of same and different, original and copy. This is the turning of the troping of metonymy... the mimetism of ludic repetition or supplement that exposes the operations of representation as the production of value within an economy of meaning configured by a specific set of overlapping signifiers. The metonymic infiltrating the metaphoric making (im)possible philosophy/theory, translation and gender. Instead of an exchange of signs constituting the identity of differing groups, there is only the change of signs in a combinatory of provisional groupings that announces the reign of the signifier. Reading from one signifier to another, connecting one signifier with another... Translating with the signifier, as it is contaminated by another while past and future configurations commingle, thickening the web of relations... The possibilities for expanding meaning overflow, excessive, limited temporarily only by the pragmatic 
contingencies of the specific instance of utterance. The utterance. Irigaray's critique of systems of exchange articulates the necessity of pragmatics. It matters who is speaking to whom and under what conditions.

What is at stake here is a shift from a relationship between interpretation and the object of interpretation to a concern with the implications of that particular interpretation. This engages a shift from an axiological to an ethical theory and practice of translation, which investigates the environment of a given performance.

\section{Metonymy in the text of translation or:}

Traducing by lapse and bounds

Traducing by "lapse and bounds" (Cixous, 1986, p. 96). Translating by lack or excess. In conclusion, I want briefly to take up this question of an ethics of translation to investigate the effects of a performance through the "interpretive lever" introduced by Irigaray, of a rereading to examine the operations of figures of discourse, the imaginary configurations and metaphoric networks of a specific praxis. What happens to the network of "antre"/"entre" when it is transformed from French to English? A shift from a regime of heterogeneity to enter a regime of analogy - this is the story of the translation of Irigaray's Speculum de l'autre femme. In contrast, is the story of the translation of Cixous's Vivre l'orange, her first published version of a "reading with Clarice Lispector" where reading is a complex process of interlingual translation among several languages. The book is produced bilingually, with French and English texts facing each other. Puns, multilingual polysemic word plays, proliferate across languages, setting in play a chain of signifiers that produces an inter-language moving between English, French, Portuguese in a textual contamination, transformation. What these two translations enact are some of the possible strategies of handling metonymy in the text of translation. Briefly, in what follows, I want to examine the strategies used for translating the word play in the texts of these two French feminist theorists, for the punning, as I have shown, both introduces the key "metaphors" of their theoretical systems and deploys the strategy of self-reflexive mimicry. This foregrounding of the metonymic occurs through the slippage of meaning along the chain of combination as 
signifier connects with signifier, sliding across the bar of the signified, in a (dis)play of laughter (wit) that reorganizes the economy of the logos (Lacan 266).

There are other strategies of rereading that would explore the contingencies of the discursive fields of French and English feminism on these translations; examine the processes of translation through analysis of the characteristic strategies of translators in translating for the letter or for the meaning as exhibited in their other translations, or through the specific choices effected during translation as revealed in a narrative account of the process. What all these approaches share is a concern for attention to the production of meaning in translation rather than for a re-covery of meaning or an evaluation of the truthfulness of "copy" to "original." In this, they address attention to the translator-effect, that is to the translator as the place at which the process of infinite semiosis is halted within an utterance that works to produce political effects. The focus is on who the translator is, for whom the translation is being produced, under what conditions the translation is being constructed. This raises questions about the imbrication of power and truth. Who gets to fix or determine the relations between signifiers and signified that produce signification or truth (i.e. convention) in a particular discursive instance? These engage questions of the literary institution, the structure of desire in the transferential relation between subject and object of translation (Godard, 1989), the production of translators, the self-reflexivity of the translation process (Godard, 1986, 1990), the demystification of translation as a transformative process of production of meaning (Godard, 1991).

To fully articulate the translator-effect as it is operative in the translation of texts by Luce Irigaray and Hélène Cixous would require an analysis of the polysystems of French and American literary institutions, especially the articulation of feminist discourses within these systems and the translation norms at work (Godard, 1987). Such transference mechanisms constrain the selection and manipulation of feminist texts in their movement from one language system to another. Generally, in this instance of translation into a non-canonical system, the texts entering the feminist system use the behaviour patterns and models prominent in the canonized system of the target language with the effect of turning the different into the same. The work of transla- 
tion is hidden in a theory of language and translation that assumes the transparency of the signifier. This is most evident in the translations of texts by Luce Irigaray, published by American university presses. However, the first translated work by Hélène Cixous was published by the French press, des femmes, directed at an anglophone readership within the circumference of the French literary institution. That this translation was a collaborative venture with Cixous aided by two anglophones amplifies the differences between the two practices: vivre $l$ 'orange is an instance of self-translation, rather than translation of work by another, and so belongs to a different mode of rewriting as the repetition of a process rather than the repetition of a product. Because of its position within the French feminist discursive system, the translation of vivre l' orange had little impact on the norms of translation for other French feminist texts, though it established a model for translation of Cixous's work into English. Translations of Irigaray's work on the contrary attracted considerable attention from American feminists. However, they discussed the texts as though written in English and not subjected to the transformative process of translation. The translation in question adopted a strategy other than that generated by the metonymic theory of exchange articulated by Irigaray: it muted the metonymic displacements, reading the text as unary discourse not as transformative signifying practice. The reception of this discourse by American feminists compounded the effect of the in-different translation practice, accusing Irigaray of essentialism (Jones, p. 367), reading the body in a network of biological signifiers rather than as discursive construction deliberately assumed in order to expose the metonymic contingencies of gender operative in the texts of theory. The narrative of the franco-american disconnection can be read elsewhere (Godard, 1987). It is a problem in discourse where conflicting discursive configurations of meaning have poliferated as an effect of translation.

A major difference between the two translation practices is situated in the relative attention given to the signifier. Translation for meaning differs from translating to the letter. Briefly, I want to illustrate the implications of these questions in respect to the translation of polysemy. As I have suggested, the slippage of the signifier is crucial to the way Irigaray stages her argument as well as in articulating the issues at stake in this argument. In Gillian Gill's translation of Speculum, polysemy is not-translated, nor is a compensatory system of 
explication of the choices established. The complex of terms which in French articulate overlapping networks around the concepts of similarity, identity, subjectivity, literal meaning, property, propriety or the law, are fixed in singular English terms that break their connecting metonymic chains of signifiers. So "non-propre" (Irigaray, 1974, p. 274) is translated as "non-propertied" (Irigaray, 1985a, p. 291). Possession, ownership, is stressed here, and the other possible significations of non-literal or figurative, contamination, improper or against the law, are not brought into play so that the signifier "propre" is articulated only within a network of objects and bodies and not within an additional network of discourses and conventions.

Similarly, the terms "même" and "autre," which produce overlappings in French between oppositions around the semantic fields of self/other and same/different, are translated by one of the possible English signifiers, so that in the context of the discussion of the shadows in the Platonic cave, "les (mêmes) autres" (Irigaray, 1974, p. 338) is rendered as "the (like) others" (Irigaray, 1985a, p. 272) with the result that, in English, the question of mimesis is separated from that of subjectivity and sexual difference. It is just the collapsing of boundaries between these discursive categories that the French text stages. So too it is the polysemic contamination of the room or enclosure of the philosopher's enforced shadow-play by the concepts of passage, movement and change which is staged in the overlapping of "enceinte" as enclosure and pregnant and of "antre" (Irigaray, 1974, p. 347) as cave and in-between ("entre"), cave and womb ("ventre"). Translated as "stronghold" and "den" (Irigaray, 1985a, pp. 278-279), the play of the signifier is fixed in a singular "proper" meaning, ironically playing out the scenario of the philosopher "trapped in a single metaphorical project" (Irigaray, 1985a, p. 279) which this text is trying to unfix by staging a scenario in which everyone is caught up in a "mimodrame," in "mimétisme" or "mimicry" (Irigaray, 1974, p. 349; 1985a, p. 280), where there is no single "proper" meaning but only fictions of identity (Irigaray, 1985a, p. 281) contingent on gender.

The philosopher's construction of himself as transcendental subject through the re-covery of a singular meaning is figured by Irigaray as a gendered act of "re-con-naissance," metonymy that is repressed by the metaphorical project. In these cases of polysemy, there 
are obvious difficulties in translation since the semantic fields of English and French terms are different. Various compensatory strategies of non-translation have been deployed by Catherine Porter in her later translation of This Sex Which Is Not One, notably the addition of a glossary which gives a detailed explanation of the multiple signifieds for the signifiers in question. Another such strategy which foregrounds the polysemy in the act of reading is to cite all the possibilities at each textual occurrence (Cixous, 1986, p. 80). Neologisms might be produced to foreground such work on the signifier, as with "knowing herself cunt birth" for "re-con-naissance" (Cixous, 1986, p. 91). Or polysemy might be introduced where such possibilities present themselves in the target language as in "booby trapped silence" for "silence piégé" (Cixous, 1986, p. 93). This is the strategy of translating by "lapse and bounds" as Betsy Wing puns in English to reproduce the signifying effect of Cixous's text in The Newly Born Woman. "Winging it" in order to "voler" language.

The model for this translation practice is the text manipulated by Cixous and her colleagues, vivre l'orange which literally "does languages" as it "makes language" ("Je fais des langues" Cixous, 1979, p. 21). This text responds to the "Éclat" of "Clarice" (Lispector) (Cixous, 1979, p. 27) with a movement into the other that results in a (con)founding of languages, voices, texts. A theory of translation as combination is elaborated in this text in the contamination of French, Portuguese and English, as Cixous follows the course of the orange, "a beginning" (Cixous, 1979, p. 20) from which all courses are possible including the recognition that "the love of the orange is political" (Cixous, 1979, p. 26) as well as the return to the source - "All the orient is orange" (Cixous, 1979, p. 32) - through the bright colours of Lispector's Brazil back into her own childhood world of North Africa with its succulent and brilliant blood-oranges, and through the chain of signifiers in a phonetic translation to "Oran-je," and her birth city Oran, on to a reflection on the permeability of boundaries in "I/ran" (Cixous, 1979, pp. 31-32). Sound chases sound, slips under the noun and merges with all forms (Cixous, 1979, p. 37).

Reaching out with the tongue into the translation of the orange into apple is to move toward Edenic innocence, implicated in a double movement which is mis-translation. The phrase "love of orange," 
guiding principle in her immersion course in other tongues, other languages, is at the root of her guilt, is "Original Sin," because the apple has been situated in the beginning, an apple in the darkness. In the "translation of the apple (into orange) I try to denounce myself" (Cixous, 1979, p. 40). This desire to become "simple as an apple," where all is play and pleasure, is not to encounter innocence, but guilt, alterity. The encounter with Clarice involves the recognition that "Far from the orange... I am unforgiveable. I am foreinge" (Cixous, 1979, p. 40). Despite the assonance, "origin" is far from "orange" (Cixous 1979, 14): it is instead "foreinge." The continual slippage of signifiers foregrounds the aporia of translation. Everything is the same; everything is different, foreign. Everything is translation: nothing is translatable.

The problem of writing, of doing languages, is framed as a problem of translation: "Comment s'appeler à l'étranger" which is translated as "How to call oneself abroad?" (Cixous, 1979, p. 36). A broad? This is rephrased as "How to call myself a woman?" (Cixous, 1979 , p. 38). The orange here is an "open, bottomless species" that "keeps alive and circulates, with life, death, women, forms, volumes, movement, matter, the ways of metamorphoses..." (Cixous, 1979, p. 18; p. 16). This is the work of translation, to "re-knew" connections (Cixous, 1979, p. 52) and animate fragments. This is the work of Clarice as writer who goes into the darkeness with hands like voices and "holds words out in the direction of things like infinitely moving fingers, finding directions, sense." Clarice "en son-je," Clarice "en songe" and using sound, the polysemic possibilities of language, calls the reader in foreign names, helps one to become "self-strange" and come to language (Cixous, 1979, p. 38). "Laranja" she calls the canvas for the text, the orange, oran-je, laranja, langue, "Lalgeria": "naranja, she translated it into my tongue, and I rediscovered the taste of the lost orange, I re-knew the orange" (Cixous, 1979, p. 52). The flash, the "éclair" of Clarice, or the translation effect, forges connections across languages, between texts, as the one goes out into the other, (con)fuses as the one within the other.

Cixous's text is a both a meditation on and a staging of translating with the signifier, moving between Portuguese and French and opening up the possibilities for creation through the encounter with 
difference. The English version of the text compounds the translation effect, by proliferating the play among three languages, developing the polysemic possilities in English with the neologism "foreinge" and the changed spelling of "re-knew." As well, the translation foregrounds its foreigness by translating for the letter, introducing "regards" in a passage where "looks" would have been more colloquial (Cixous, 1979, p. 24) and leaving "Mongolfier" sitting like a boulder in a field after the passage of a French glacier (Cixous, 1979, p. 22). Then there is the attempt to maintain some of the polysemy in phrases such as "toutes les relations de sens que toute orange maintient en vie" which becomes "including all the sense relations that every orange keeps alive" (Cixous, 1979 , p. 17; p. 16). While "senses" loses its meaning of direction where it is retained, it slips and slides between "meaning" and "sense," a knot of associations central to vivre l'orange where the impossibility of "proper meaning" is staged through the processes of associative linking around the senses of hearing, seeing, touching and smelling the orange. Here the translators have opted to restage the combinatory work along the phonemic chain rather than fix on a single meaning.

What I have been exploring here are the contrasting effects of translating for the signified (under the reign of metaphor) and translating for the signifier (under the reign of metonymy). In the former, the sign of translation is written as a double sign, similar to that of metaphor, where $\mathrm{Se}$ is attached to both $\mathrm{Sal}$ and $\mathrm{Sa2}$. In the second case, translation attentive to the letter, following from signifier to signifier, proliferates new possible signifieds with each new configuration of signifiers, so that $\mathrm{Sal}$ and $\mathrm{Sa} 2$ produce $\mathrm{Se} 1, \mathrm{Se} 2, \mathrm{Se} 3$, etc. The slippage of signifiers is endless. The virtual potentials for signifieds are constrained by the contingencies of the specific actualization, but as in a combinatory, may be reorganized and actualized in new configurations. Translating for the letter opens up the play of the signifier beyond the "literal" meaning of the word. This is the work of the metaphor that is not a metaphor, but a metonymy. The translation that is not a translation, but a contamination, a hybrid, touching on, living on... The (im)possibility of translation/theory. 


\section{Works Cited}

DE BEAUVOIR, Simone (1949). Le deuxieme sexe. Paris, Gallimard.

BENJAMIN, Andrew (1989). Translation and the Nature of Philosophy: A New Theory of Words. London and New York, Routledge.

BERMAN, Antoine (1984). L'Épreuve de l'étranger. Paris, Gallimard.

BINHAMMER, Katherine (1991). "Metaphor or Metonymy? The Question of Essentialism in Cixous," Tessera, 10 (Summer), pp. 65-79.

BUTLER, Judith (1990). Gender Trouble: Feminism and the Subversion of Identity. New York and London, Routledge.

CIXOUS, Hélène and Catherine Clément (1986). The Newly Born Woman. Trans. Betsy Wing. Minneapolis, University of Minnesota Press.

(1990). Reading With Clarice Lispector. Ed. and Trans. Verena Andermatt Conley. Minneapolis, Minnesota Press.

(1979). Vivre l'orange. Trans. an Liddle and Sarah Cornell. Paris, des femmes.

COWIE, Elizabeth (1990). "Woman as Sign," in The Woman in Question: $M / F$. Eds. Parveen Adams and Elizabeth Cowie. Cambridge, MIT Press, pp. 117-133.

DERRIDA, Jacques (1967). "De l'économie restreinte à l'économie générale, Un hégélianisme sans réserve," in L'écriture et la différence. Paris, Seuil, pp. 369-407.

(1982). "White Mythology: Metaphor in the Text of Philosophy," in Margins of Philosophy. Trans. Alan Bass. Chicago, University of Chicago Press, pp. 207-271. 
ECO, Umberto (1976). A Theory of Semiotics. Bloomington, Indiana University Press.

GALLOP, Jane (1988). "The Body Politic," in Thinking Through the Body. New York, Columbia University Press.

GODARD, Barbara (1986). "Preface," in Lovhers. Nicole Brossard. Trans. Barbara Godard. Montréal, Guemica.

(1987). "Translating French Feminism." Paper read for the Canadian Association of Comparative Literature, Learned Societies, McMaster University, Hamilton, May 1987.

(1990). "Theorizing Feminist Theory/Translation," in Translation: History and Culture. Eds. Susan Bassnett and André Lefevere. London, Frances Pinter, pp. 87-96.

(1991). "Essay/ons Traduction/Translation." Forthcoming in proceedings of "Feminist Theory: an International Debate." London, Routledge.

GOLDMAN, Emma (1970). The Traffic in Women and Other Essays on Feminism. Albion, Cal., Times Change Press.

HJELMSLEV, Louis (1969). Prolegomena to a Theory of Language. Trans. Francis J. Whitfield. Madison, University of Wisconsin Press.

IRIGARAY, Luce (1987). Sexes et parentés. Paris, Minuit.

(1985a). Speculum of the Other Woman. Trans. Gillian Gill. Ithaca, Comell University Press.

(1985b). This Sex Which is Not One. Trans. Catherine Porter. Ithaca, Cornell University Press.

JAKOBSON, Roman (1963). "Aspects linguistiques de la traduction," in Essais de linguistique générale. Trans. Nicolas Ruwet, Paris, Minuit. 
JONES, Ann Rosalind (1985). "Writing the Body: Toward an Understanding of l'Écriture féminine," in The New Feminist Criticism: Essays on Women, Literature and Theory. Ed. Elaine Showalter. New York, Pantheon, pp. 366-377.

LACAN, Jacques (1966). "L'instance de la lettre dans l'inconscient ou la raison depuis Freud," in Écrits. T. I. Paris, Seuil, pp. 249-289.

LEFEVERE, Andre (1985). "Why Waste Our Time on Rewrites? The Trouble with Interpretation and the Role of Rewriting in an Alternative Paradigm," in The Manipulation of Literature. Studies in Literary Translation. Ed. Theo Hermans. London, Croom Helm.

KRISTEVA, Julia (1982). Powers of Horror: An Essay in Abjection. Trans. Leon S. Roudiez. New York, Columbia University Press.

LÉVI-STRAUSS, Claude (1969). The Elementary Structures of Kinship. Trans. James Harle Bell, John Richard von Sturmer and Rodney Needham. Boston, Beacon Press.

(1967). Structural Anthropology. Trans. Claire Jacobson and Brooke Grundfest Schoepf. New York, Doubleday.

MAUSS, Marcel (1966). The Gift: Forms and Function of Exchange in Archaic Societies. Trans. Ian Cunnison. London, Cohen and West.

DE SAUSSURE, Ferdinand (1966). Course in General Linguistics. Trans. Wade Baskin. New York, McGraw Hill. 